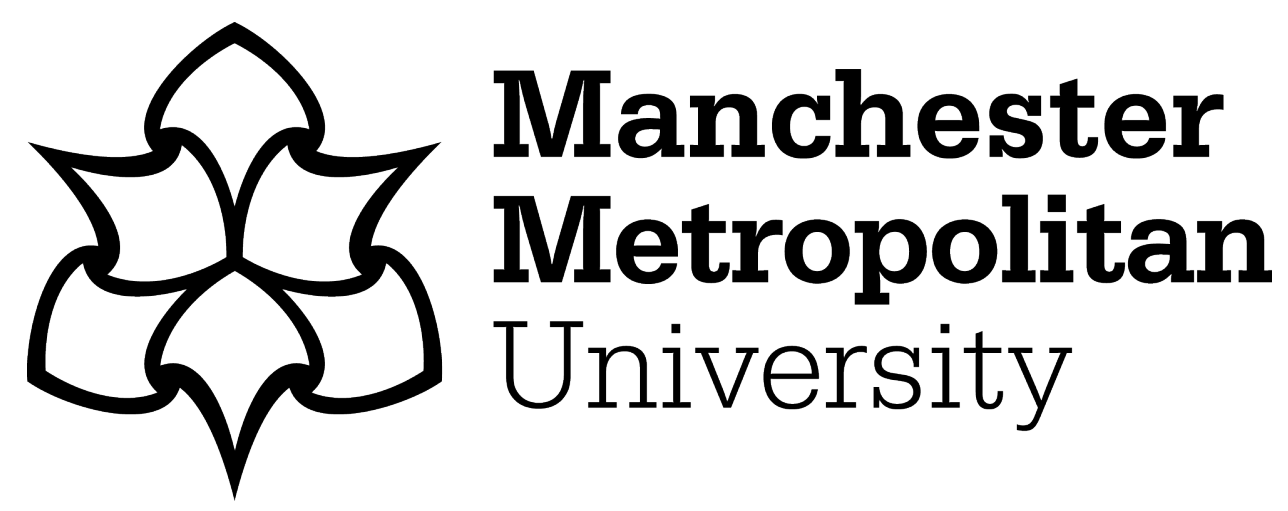

Antonini, Francesca, Bernstein, Aaron, Fusaro, Lorenzo and Jackson, Robert ORCID logoORCID: https://orcid.org/0000-0002-6195-1067 (2019) Introduction: Gramsci Past and Present. In: Revisiting Gramsci's Notebooks. BRILL, pp. 1-6. ISBN 9004417699

Downloaded from: https://e-space.mmu.ac.uk/625958/

Version: Accepted Version

Publisher: BRILL

DOI: https://doi.org/10.1163/9789004417694_002

Please cite the published version 
[pre-peer reviewed manuscript]

in Antonini et alii (eds), Revisiting Gramsci's Notebooks, Leiden, Brill 2019, pp. 1-6.

https://brill.com/view/book/edcoll/9789004417694/BP000001.xml

Francesca Antonini, Aaron Bernstein, Lorenzo Fusaro and Robert Jackson

\section{Introduction: Gramsci Past and Present}

The legacy of the Italian theorist Antonio Gramsci (1891-1937) has been widely acknowledged as one of the most significant intellectual contributions of the twentieth century. A crucial element in Gramsci's perspective is his profound sense of the manifold connections between the past and the present. This nexus between explication of the past and strategic analysis of the present is characteristic of the originality of Gramsci's approach. The heading 'Past and Present' is used by Gramsci as an instrument in the organisation and development of his thought, and it constitutes one of the most prominent themes in the Prison Notebooks. ${ }^{1}$

On a more general level, Gramsci's ability to dialectically combine seemingly opposed elements in a relationship of unity-distinction (i.e. civil society and the state, structure and superstructure, the spatial elements of historicism, or vice versa the multiple temporalities going across political space) illuminates the capacity of his thought to stimulate critical renewals in various domains of thought. Further investigation of this critical project reveals the aspect of reciprocal 'translatability' that Gramsci identifies between different facets of the knowledge of reality as philosophy, politics and economics. In other words, it brings into relief the idea of a 'homogeneous circle', ${ }^{2}$ that is, the constitution of Gramsci's conception of the world and its relation to history, understood as a unitary and dynamic process.

This framework was explored by a two-day international conference held at King's College London and organised by a group of young Gramscian scholars (Past and Present: Philosophy, Politics and History in the Thought of Antonio Gramsci, 18-19 June 2015). The conference brought together forty-five scholars from sixteen countries. The present volume represents a selection of chapters developed from the presentations of the participants. It contains twenty-five distinctive contributions representing a growing global network of Gramscian thinkers ranging from early-career researchers to experienced scholars.

Strongly focused on the research carried out by early-career participants of the London conference, the principal aim of the book is to give voice to a new generation of scholars working on Gramscian themes. Taking its cue from the methodology of the

1 On this topic, cf. the entry Passato e presente by Fabio Frosini in Liguori-Voza 2009, pp. 626-28.

2 Q 4, § 46, p. 472; Gramsci 1971, p. 403. 
best outputs of recent Gramscian scholarship, the essays collected here offer an innovative and fresh insight into Gramsci's thought. They also illuminate the promising trajectories of future Gramscian research projects.

While originating from different points of view, our collective intention is to investigate in the broadest sense the rich potentialities of the theme 'Past and Present'. We aim to explore this framework by analysing the conceptual laboratory of Gramsci's historicalpolitical narration, as well as his endeavour to theorise the unity of theory and practice. More broadly, we aspire to study the way in which Gramsci's historical perspective intermingles with his engaged concern for the future of a 'great and terrible' world, ${ }^{3}$ in a critical sense of what might today be called 'global history'.

In fact, the investigation of Gramsci's thought cannot be separated, as Peter Thomas affirms, from the awareness of living in a 'Gramscian moment'. ${ }^{4}$ This volume represents a collection of new research on Gramsci at a point in time when his thought has increased in influence and become diffused across a broad spectrum of disciplines. In the last decades, Gramscian notions have spread through philosophy to history and geography, through cultural theory and subaltern studies, to international relations, linguistics, critical legal studies and beyond. ${ }^{5}$

It is exciting evidence of the enduring capacity of Gramsci's thought to generate and nurture innovative inquiries across diverse themes. The chapters of this book engage with on-going debates in these different fields of study and aim to offer a key to interpret their most recent trends.

The novelty of the collection lies not only in its content but also in the methodology it applies. In light of the widespread and heterogeneous deployments of Gramscian ideas, it seems apt and necessary to return to the texts themselves: Gramsci's preprison and his prison writings, both the Prison Notebooks and the Letters from Prison. ${ }^{6}$ We are convinced that a rigorous textual analysis is the unavoidable condition for a deeper understanding of his work and, consequently, for a fruitful interaction between Gramscian concepts and other theoretical and historical frameworks.

In this respect, the book capitalises on the philological tradition of studying Gramsci that has flourished in recent decades, especially in Italy. As Fabio Frosini notes in his

3 This is an expression from Rudyard Kipling adopted by Gramsci in letters to his wife Jul'ka; cf. Gramsci 2014.

4 Thomas 2009.

5 Gramscian scholarship has been undergoing a new season of publications, including recent edited collections assessing the contemporary relevance of his thought, such as Green 2011 and McNally 2015. A number of volumes have also explored and applied his thought in diverse fields, such as migration studies (Agustín and Jørgensen 2016), critical theory (Kreps 2015), geography (Ekers et al. 2013), subaltern studies (Zene 2013), post-colonial theory (Srivastava and Bhattacharya 2012), linguistics and translation studies (Ives and Lacorte 2010), and education (Mayo 2010).

6 The critical edition currently available in English is Gramsci 1992-2007. The first three volumes of the English critical edition of the Notebooks, edited by Joseph Buttigieg, currently provide up to Notebook 8. The most widely available anthologies of the Notebooks in English are Gramsci 1971 and 1995. 
survey of the development of Gramscian scholarship over the last fifty years, ${ }^{7}$ the publication first of the critical edition of the Prison Notebooks edited by Valentino Gerratana (1975), and then of Gianni Francioni's L'officina gramsciana [The Gramscian Laboratory] (1984), ${ }^{8}$ has affirmed a new approach towards the study of Gramsci's work. While Gramsci's writings have been subjected at times to a process of systematic reordering that obscured the dialectical emergence of his ideas, they are increasingly read as texts characterised by a constitutive incompleteness, for both external and internal reasons. ${ }^{9}$ Consequently, they require the type of careful diachronic and philological approach that has been developed and refined in recent years, thanks both to individual contributions, ${ }^{10}$ and collective initiatives, ${ }^{11}$ which have culminated in the ongoing publication of the new critical 'National edition' of Gramsci's works. ${ }^{12}$

The volume represents a timely encounter of diverse interpretations of Gramsci's ideas with a philological reading of his work. As a longer-term goal, we aim to promote an engagement with the recent achievements of Italian Gramsci scholarship in order to develop a deeper appreciation of and dialogue with them. In the past, studies of Gramsci, especially in the anglophone world, have lacked the resources to engage fully with the process of development of Gramsci's writings. ${ }^{13}$ In contrast, we are now working towards an assessment of the more subtle 'rhythms' of Gramsci's thought.

Furthermore, the book attempts to transcend existing national and 'continental' boundaries within academia, gathering scholars from thirteen different nationalities and from across the globe. In this sense, the volume aims to contribute to the concrete construction of a 'global' Gramscian community that relies on common methodological achievements.

Finally, this philological approach does not imply a dismissal of contemporary readings of Gramsci; on the contrary, it draws attention to neglected aspects of his thought and

7 Frosini 2008. See also Vacca 2011.

8 See Francioni 1984 on the structure of the notebooks. This text also contains a strong criticism of Perry Anderson's article 'The Antinomies of Antonio Gramsci' (Anderson 1976). Despite this extensive criticism, Anderson's article remains one of the most influential readings of Gramsci in the Anglophone world. For a detailed account in English, see Thomas 2009, pp. 41-83. Anderson has recently republished this text as a book with a new Preface, which all too briefly undertakes a condensed explanation of these criticisms (see Anderson 2017).

9 These reasons relating to, respectively, his confinement in prison and his open methodology, cf. Thomas 2009, pp. 85-131, in particular p. 126ff.

10 Some of these contributions are now available in English, such as Cospito 2016 [2011], and Liguori 2015 [2006].

11 These collective initiatives include the ongoing seminars organised by the International Gramsci Society Italia in Rome. The first cycle of this seminar (2000-03) was held on the lexicon of the Prison Notebooks, and its results published in Frosini and Liguori 2004. The second cycle (2004-06) was also focused on some key Gramscian categories, while the third, on the history of the Notebooks, is ongoing (2012-). Two of the most significant initiatives, in different formats, have been the Dizionario gramsciano (Liguori-Voza 2009), and the Ghilarza Summer Schools 2014 and 2016, residential courses of advanced study on the thought of Gramsci for early career researchers.

12 An Edizione nazionale (National Edition) of the work of Antonio Gramsci is currently in preparation in Italian (see Frosini 2008, and the special issue of Studi Storici (4, 2011)). In addition, an 'anastatic'version of the Notebooks, which reproduces the Notebooks in photographic form, has been published under the editorship of Gianni Francioni (Gramsci 2009).

13 On this point, see Thomas 2009. 
sheds a new, meaningful light on pressing issues of our historical conjuncture, as many of the contributors here amply demonstrate. This testifies to the status of Gramsci's work as a modern 'classic', capable of being 'contemporary' in different times. ${ }^{14}$

The structure of the volume is divided into the following eight sections: Global Gramsci: Gramscian geographies; Language and Translation; Gramsci and the Marxian legacy; Subalternity between pre-modernity and modernity; Postcolonial and anthropological approaches; Culture, Ideology, Religion; Historical Capitalism and World History; and Readings of Gramsci.

Global Gramsci: Gramscian geographies contends, on the one hand, that Gramsci's thought makes an important contribution to extant discussions within critical geography and presents the Italian author as a geographical historical materialist (Loftus). On the other hand, Roccu and Buddharaksa deploy Gramsci's writings to comprhend contemporary political and economic development in Egypt and Thailand.

The section on Language and Translation focuses on Gramsci's distinguished analysis of language, sketching a fascinating structural parallel with his concept of ideology (Boothman), and emphasising how the Gramscian conception of language as a social and historical process contrasts with positivist currents in linguistics (Sućeska). Finally, Wróblewska examines the translations of Gramsci's texts from the point of view of his own complex theory of translation and translatability.

The section Gramsci and the Marxian legacy addresses the relation between Marx and Gramsci from a philosophical point of view, thereby addressing Gramsci's distinctive conception of revolution (Frosini), and points to some of the distinctive aspects of Gramsci's reformulation of Marx's thought as a philosophy of praxis (Bernstein). Furthermore, Antonini discusses the crucial role that historical analogy plays for the two authors.

The fourth section, Subalternity between pre-modernity and modernity, casts new light on the concept of the 'subaltern', interpreting the latter as exploited and as included, albeit 'passively', within hegemonic power structures (Thomas). While Freeland provides the reader with a combined analysis of Gramsci's categories of subalternity and the national-popular, Meret takes Gramsci's writings as a point of departure for analysing the pressing issues of space, mobility, migrant struggles, and subalternity.

In close thematic connection, the following section (Postcolonial and anthropological approaches) newly interprets the 'Southern question', taking account of recent insights into Gramsci's understanding of subaltern groups (Conelli). The latter are also chosen as a point of departure for Vandeviver, who makes the claim that Gramsci's conception of subalternity enables a fresh interpretation of Edward Said's Orientalism, as opposed to common readings based on Foucault. On the other hand, Ciavolella assesses the

14 See Thomas 2009, p. 130, as well as Frosini 2008, p. 670. 
influence of Gramsci's ideas on anthropology and on the development of a 'popular politics'.

The section Culture, Ideology, Religion opens with Gramsci's critique of the Catholic Church, highlighting how it differs from that of Benedetto Croce, and is developed from the failures of the latter (Chino). The chapter by Pohn-Lauggas discusses aesthetics, politics and Gramsci's substantiveengagement with literature, showing how the latter should be taken into consideration in order better to grasp Gramsci's heterogeneous notes entitled 'Past and Present'. Finally, Jackson argues for the significance of a rarely studied concept in the Gramscian lexicon, the mummification of culture, and its critical function in overcoming the enduring influence of the 'living dead'.

The seventh section, Historical Capitalism and World History, stresses the novel contribution that a return to Gramsci's writings makes for our understanding of the transition from feudalism to capitalism, highlighting the dialectical relation between structure and superstructures (Douet). By pointing to Gramsci's state-centric analysis within the Notebooks, Fusaro comprehends international relations in a way that strongly contrasts with established neo-Gramscian analyses. Moreover, Settis' contribution casts new light on the Gramscian concept of 'Fordism'.

The final section, Readings of Gramsci, collects four essays that analyse the interpretations of Gramsci's thought that have been offered in the second half of the twentieth century in Italy, Latin America and France. While Panichi provides a critical discussion of the interpretation of Gramsci advanced by Norberto Bobbio, Cuppi focuses on the readings by José Maria Aricó, Juan Carlos Portantiero and Carlos Nelson Coutinho. The last two contributions, based on original archival research, illuminate respectively the diffusion of Gramsci's work in France (Crézégut) and its reception by Althusser (Neubauer).

To conclude, the book offers a window onto the ongoing development of a new generation of Gramscian scholars traversing diverse national contexts. Furthermore, it provides a distinctive approach aimed at drawing out the elements of coherence across these new projects and situating them, not as a series of individual elaborations, but within the ambit of a coordinated and collective international project.

[September 2017] 


\section{References}

Agustín, Óscar García, and Martin Bak Jørgensen (eds) 2016, Solidarity without Borders. Gramscian Perspectives on Migration and Civil Society, London: Pluto Press.

Anderson, Perry 1976, 'The Antinomies of Antonio Gramsci', New Left Review, I, 100: 5-78.

Anderson, Perry 2017, The Antinomies of Antonio Gramsci, with a new Preface, London: Verso.

Cospito, Giuseppe 2016, The Rhythm of Thought in Gramsci. A Diachronic Interpretation of Prison Notebooks, Leiden: Brill [translation of: 2011, Il ritmo del pensiero: per una lettura diacronica dei Quaderni del carcere di Gramsci, Napoli: Bibliopolis].

Ekers, Michael and Gillian Hart, Stefan Kipfer, Alex Loftus (eds) 2013, Gramsci: Space, Nature, Politics, Oxford: Wiley-Blackwell.

Francioni, Gianni 1984, L'officina gramsciana. Ipotesi sulla struttura dei «Quaderni del carcere», Napoli: Bibliopolis.

Frosini, Fabio 2008, 'Beyond the Crisis of Marxism: Gramsci's Contested Legacy' in Critical Companion to Contemporary Marxism, edited by Jacques Bidet and Stathis Kouvelakis, Leiden: Brill.

Frosini, Fabio and Guido Liguori (eds) 2004, Le parole di Gramsci. Per un lessico dei "Quaderni del carcere", Roma: Carocci.

Gramsci, Antonio 1971, Selections from the Prison Notebooks, edited and translated by Quintin Hoare and Geoffrey Nowell-Smith, London: Lawrence and Wishart.

Gramsci, Antonio 1992-2007, Prison Notebooks, 3 Volumes, edited by Joseph A. Buttigieg, New York: Columbia University Press.

Gramsci, Antonio 1995, Further Selections from the Prison Notebooks, edited by Derek Boothman, Minneapolis: Minnesota University Press.

Gramsci, Antonio 2009, Quaderni del carcere. Edizione anastatica dei manoscritti, edited by Gianni Francioni, Roma-Cagliari: Istituto della Enciclopedia Italiana-L'Unione Sarda.

Gramsci, Antonio 2011, Letters from Prison, 2 Volumes, edited by Frank Rosengarten, New York: Columbia University Press.

Gramsci, Antonio 2014, A great and terrible world: the pre-prison letters 1908-1926, edited and translated by Derek Boothman, London: Lawrence and Wishart.

Green, Marcus E. (ed.) 2011, Rethinking Gramsci, New York: Routledge.

Ives, Peter and Rocco Lacorte (eds) 2010, Gramsci, Language, and Translation, Lanham, MD: Lexington Books.

Kreps, David (ed.) 2015, Gramsci and Foucault: A Reassessment, Farnham, Surrey: Ashgate.

Liguori, Guido and Pasquale Voza (eds) 2009, Dizionario gramsciano.1926-1937, Roma: Carocci.

Liguori, Guido 2015, Gramsci's Pathways, Leiden: Brill [translation of: 2006, Sentieri gramsciani, Roma: Carocci].

Mayo, Peter (ed.) 2010, Gramsci and Educational Thought, Malden, MA: Wiley-Blackwell.

McNally, Mark (ed.) 2015, Antonio Gramsci, Houndmills: Basingstoke: Palgrave Macmillan.

Srivastava, Neelam and Baidik Bhattacharya (eds) 2012, The Post-colonial Gramsci, New York: Routledge.

Thomas, Peter D. 2009, The Gramscian Moment, Leiden: Brill. 
Vacca, Giuseppe 2011, 'Gramsci studies since 1989', Journal of Modern Italian Studies 16.2: 179-194.

Zene, Cosimo (ed.) 2013, The Political Philosophies of Antonio Gramsci and B. R. Ambedkar: Itineraries of Dalits and Subalterns, New York: Routledge. 